Review

\title{
Thyroid Hormone-disrupting Effects and the Amphibian Metamorphosis Assay
}

\author{
Kaori Miyata ${ }^{1}$ and Keiko Ose ${ }^{1}$ \\ ${ }^{1}$ Environmental Health Science Laboratory, Sumitomo Chemical Company Limited, 1-98 Kasugadenaka 3 chome, Konohana-ku, \\ Osaka 554-8558, Japan
}

\begin{abstract}
There are continued concerns about endocrine-disrupting chemical effects, and appropriate vertebrate models for assessment of risk are a high priority. Frog tadpoles are very sensitive to environmental substances because of their habitat and the complex processes of metamorphosis regulated by the endocrine system, mainly thyroid hormones. During metamorphosis, marked alteration in hormonal factors occurs, as well as dramatic structural and functional changes in larval tissues. There are a variety of mechanisms determining thyroid hormone balance or disruption directly or indirectly. Direct-acting agents can cause changes in thyroxine synthesis and/or secretion in thyroid through effects on peroxidases, thyroidal iodide uptake, deiodinase, and proteolysis. At the same time, indirect action may result from biochemical processes such as sulfation, deiodination and glucuronidation. Because their potential to disrupt thyroid hormones has been identified as an important consideration for the regulation of chemicals, the OECD and the EPA have each established guidelines that make use of larval African clawed frogs (Xenopus laevis) and frog metamorphosis for screening and testing of potential endocrine disrupters. The guidelines are based on evaluation of alteration in the hypothalamic-pituitary-thyroid axis. One of the primary endpoints is thyroid gland histopathology. Others are mortality, developmental stage, hind limb length, snoutvent length and wet body weight. Regarding histopathological features, the guidelines include core criteria and additional qualitative parameters along with grading. Taking into account the difficulties in evaluating amphibian thyroid glands, which change continuously throughout metamorphosis, histopathological examination has been shown to be a very sensitive approach. (DOI: 10.1293/tox.25.1; J Toxicol Pathol 2012; 25: 1-9)
\end{abstract}

Key words: frog, amphibian, metamorphosis, test guideline, thyroid, histopathology

\section{Introduction}

There are many concerns about endocrine-disrupting chemical effects on wild animals as well as humans. Considerable numbers of chemicals have been shown to alter the thyroid system in vertebrates, and disruption of the thyroid axis has been identified as an important consideration for the regulation of chemicals. Thus, focusing on thyroid toxicity, the OECD and EPA established guidelines for investigation of frog metamorphosis ${ }^{1,2}$. Because amphibian tadpoles have a thin, permeable skin and inhabit aquatic environments, they are exposed to toxicants through both dermal and dietary routes and appear to be particularly susceptible to a number of contaminants in wastewater discharged from

Received: 11 August 2011, Accepted: 5 December 2011

Mailing address: Kaori Miyata, Environmental Health Science Laboratory, Sumitomo Chemical Company Limited, 1-98 Kasugadenaka 3 chome, Konohana-ku, Osaka 554-8558, Japan

TEL: 81-6-6466-5346 FAX: 81-6-6466-5354

E-mail: miyatak1@sc.sumitomo-chem.co.jp

(C)2012 The Japanese Society of Toxicologic Pathology

This is an open-access article distributed under the terms of the Creative Commons Attribution Non-Commercial No Derivatives (by-ncnd) License $<$ http://creativecommons.org/licenses/by-nc-nd/3.0/> . agricultural fields and from industrial and household areas. In addition, the fact that frog metamorphosis is regulated by thyroid hormones (THs), promoting the remodeling of the aquatic larvae into an adult tetrapod, means that the dramatic structural and functional changes of larval tissues can be readily applied as parameters reflecting endocrine disruption.

The frog thyroid glands, located between the eyes (Fig. 1), show various morphological changes during metamorphosis and under conditions of exposure to certain compounds. Here, the regulation by THs, focusing on affecting factors in addition to the metamorphosis assay, is reviewed.

\section{Thyroid Hormones and Their Related Effectors}

The thyroid gland secretes thyroxine (T4), which is converted to a more biologically active form, 3,3',5-triiodothyronine (T3), mainly in the peripheral target tissues. Transport of THs in the blood is accomplished through binding to transport proteins, predominantly transthyretin (TTR), with conjugation and degradation processes occurring in the liver and subsequent secretion in bile. Some THs are coupled with bacterial deconjugation and undergo reabsorption in the intestine. TH structures are conserved 


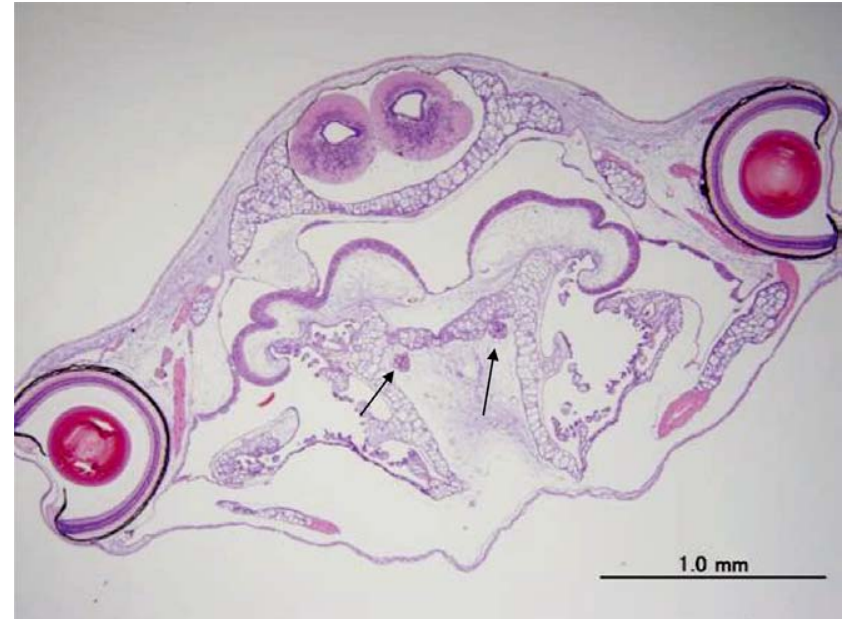

Fig. 1. Arrows indicate thyroid glands in Stage 51.

between vertebrates, and their production and secretion are essentially the same in amphibians and mammals.

There are several processes that influence the thyroid hormone balance, such as sulfation, deiodination and glucuronidation (see Fig. 2). Both inhibition of thyroidal iodide uptake and suppression of thyroidal peroxidase activity can disrupt TH synthesis and secretion. In addition, inhibition of 5-deiodinase in the peripheral tissue is related to reduction of conversion from T4 to T3, while induction of hepatic microsomal enzymes such as phenol sulfotransferase and UDP-glucuronyl transferase leads to increase in excretion of both T4 and T3 into bile. Furthermore, competitive binding to thyroid transport proteins results in reduced levels of total and free THs in serum. Therefore, there are many potential targets of environmental contaminants that could be involved in disruption of TH metabolism.

Rahman and Yamauchi found TH sulfating activity to be present in the liver cytosol in frog tadpoles and that the T3:T4 sulfating activity ratio varies during developmental stages $^{3}$, sulfation being inhibited by chemical compounds such as halogenated phenol and phenolic compounds, p-nitrophenol, dopamine, 17beta-estradiol (E2) and dihydroxyepiandrosterone. Compared with sulfation, glucuronidation has been poorly studied in amphibians, in line with its character as a relatively minor pathway. However, a subset of the responsible enzymes, glucuronidases (UGTs), can reduce circulating levels of THs through biliary elimination as in mammals. Regarding phase I species, hepatic microsomal cytochrome P450 2B1 was found to be induced by pentobarbital in adults of the semiaquatic frog, Rana pipiens, but not in frog tadpoles and adults of the aquatic frog Xenopus laevis 4 . Deiodinase enzymes, type 2 and 3 iodothyronine deiodinase, are found in several peripheral target tissues in amphibians, and the level of expression is closely connected with metamorphosis 5,6 .

The most characteristic feature of TTR from nonmammalian vertebrates, such as amphibians, is their higher affinity for T3 than for T43,7. Binding of chemicals to TTR decreases their effective free concentrations in plasma and changes the apparent affinity for THs, which can diminish cellular uptake and biological responses and would alter plasma $\mathrm{TH}$ homeostasis. Therefore, chemicals interfering with T3 binding to TTR may directly affect the free concentration of plasma $\mathrm{T} 3$ and its plasma clearance rate. Chemical compounds including diethylstilbestrol (DES) ${ }^{8,9}$,

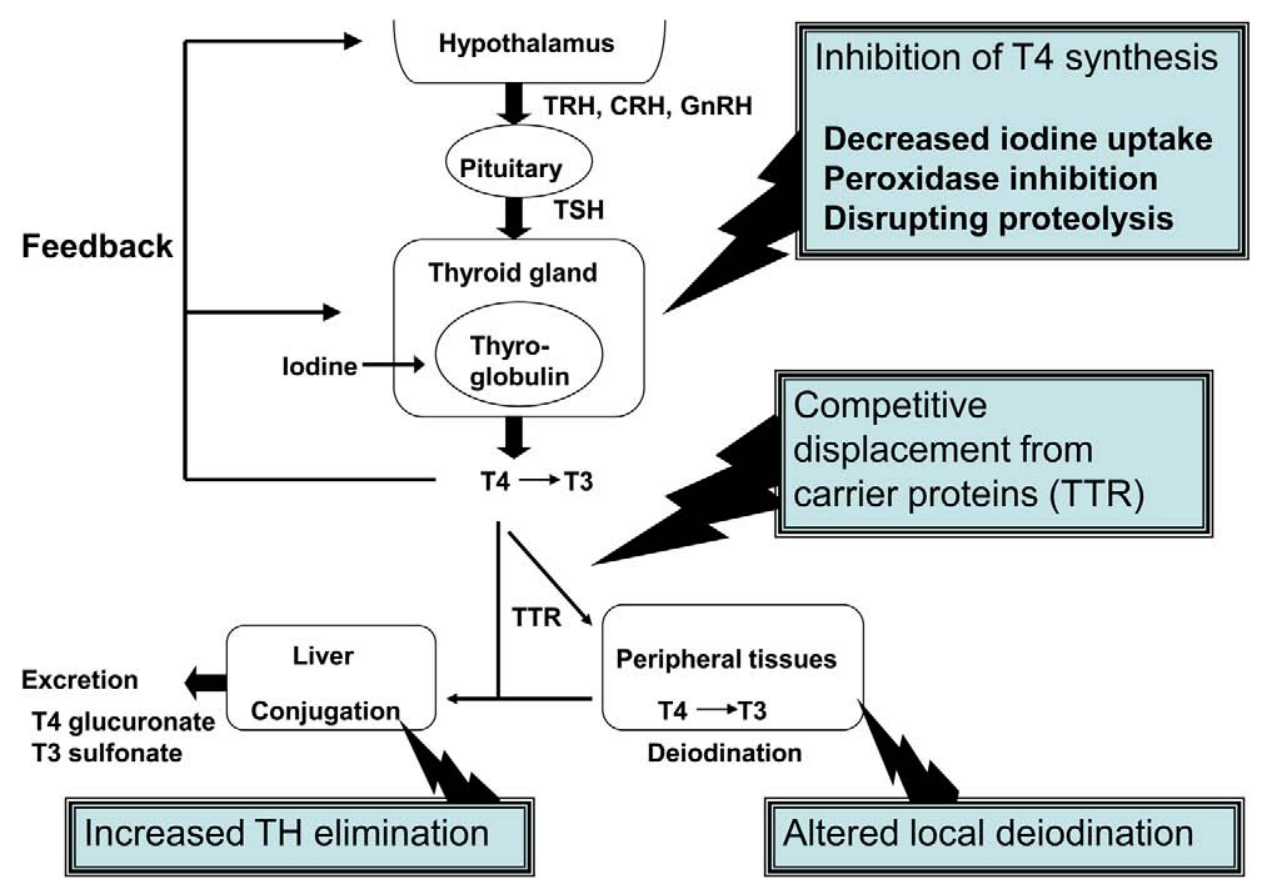

Fig. 2. Overview of the thyroid hormone pathway. 


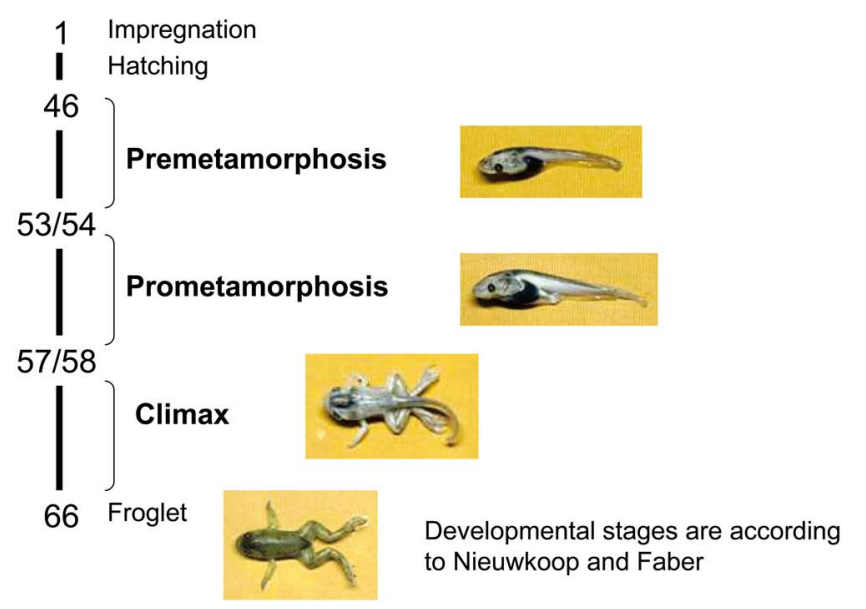

Fig. 3. The stage of metamorphosis is divided into 3 stages. The premetamorphic stage is the period until the appearance of the hind limbs, and the prometamorphic period is from their appearance to that of the forelimbs. During the period of metamorphic climax, resorption of the tail and gills and development of lungs occur.

phenolic and phenol compounds ${ }^{10,11}$ and pentachlorophenol and ioxynil 8,9 have the potential to bind to TTR, and Yamauchi et al. reported that with amphibian TTR, DES possesses similar affinity to $\mathrm{T} 3$, which is the natural ligand ${ }^{8}$.

\section{Metamorphosis and Related Hormones}

Amphibian metamorphosis is divided roughly into 3 stages, premetamorphosis, prometamorphosis and climax (see Fig. 3). The premetamorphic stage is the period until the appearance of the hind limbs, and the prometamorphic period is from their appearance to that of the forelimbs. Subsequently, during the period of metamorphic climax, resorption of tail and gills and development of lungs occur. The metamorphosis processes are systemically controlled by $\mathrm{THs}^{12-15}$. For example, treatment of tadpoles with synthetic thyroid hormone receptor antagonists (e.g., NH-3) leads to retardation or even complete blockade of Xenopus laevis (X. laevis) metamorphic development ${ }^{16}$. In turn, exposure of $X$. laevis tadpoles to low nanomolar concentrations of T3 or synthetic thyroid hormone receptor agonists (e.g., GC-1) causes precocious induction of metamorphosis ${ }^{17}$. The sensitivity to $\mathrm{TH}$ varies according to the developmental stage, and the amount of spontaneously released thyroid stimulating hormone (TSH) is higher in late prometamorphic and climactic tadpoles than in early prometamorphic larvae and juvenile and adult frogs ${ }^{18}$. Low levels of circulating thyroglobulin are found in tadpoles at the early stages, but extremely high levels are evident at the metamorphic climax ${ }^{19}$.

In amphibians, both corticotrophin-releasing hormone $(\mathrm{CRH})$ and gonadotropin-releasing hormone ( $\mathrm{GnRH})$, in addition to $\mathrm{TRH}^{23}$, have been considered as candidates for the TSH-releasing factor ${ }^{20-22}$. In the bullfrog, $\mathrm{CRH}$ was found to be the most potent TSH-releasing substance in both adult and larval pituitary cells, while both TRH and GnRH moderately stimulated the release of TSH from the adult pituitary but not larval cells ${ }^{24}$. Kaneko et al. demonstrated that TH suppressed the $\mathrm{CRH}$-induced release of TSH, but not the basal release, from larval, juvenile and adult bullfrog pituitaries in vitro ${ }^{18}$. In addition, Jacobs et al. reported that intravenously injected mammalian luteinizing hormone-releasing hormone (LHRH) was able to raise circulating levels of T4 as well as testosterone (T) in three frog species, Rana ridibunda, Rana temporaria and Rana esculenta ${ }^{21}$. Regarding prolactin (PRL), inhibitory effects may be exerted on metamorphosis, but this is controversial. Huang and Brown concluded that PRL does not play a role as a juvenile hormone in $X$. laevis, but overexpression of PRL does specifically inhibit some but not all programs of tail resorption ${ }^{25}$.

Research has indicated concomitant elevation of THs and corticoids as metamorphosis progresses ${ }^{26-28}$. According to Kikuyama et al., the aldosterone plasma level is low prior to the onset of climax, but then there is a sharp rise, and combined adrenocorticotropin (ACTH) and T treatment causes a marked increase in concentration ${ }^{28}$. Gray and Janssens observed that corticosterone stimulated T3-induced metamorphosis in X. laevis tadpoles ${ }^{29}$.

Steroid sex hormones also serve to modulate thyroid system functions. Gray and Janssens observed that testosterone and E2 inhibited T3-induced metamorphosis in $X$. laevis tadpoles ${ }^{29}$, while Hogan et al. demonstrated a delay in the time for Rana pipiens tadpoles to undergo metamorphosis when exposed to ethinylestradiol during either midmetamorphosis or throughout the entire larval period ${ }^{30}$.

\section{Effects of Chemical Compounds on Amphibian Metamorphosis}

In the past few decades, several thyroid disrupting substances have been tested for toxicity using amphibians. Xenopus and other anurans have been generally applied to assess the developmental effects of a variety of xenobiotics.

There have been a considerable number of reports regarding inhibitors of T4 synthesis that inactivate peroxidases. After exposure to propylthiouracil (PTU), also known to inhibit deiodinase, $X$. tropicalis tadpoles showed no signs of decline in body length or body weight but a considerable reduction in the developmental stage and hind limb length ${ }^{31}$. Opitz et al. reported effects of exposure to PTU and another peroxidase inhibitor ethylenthiourea (ETU), in $X$. laevis $^{32,33}$. Metamorphic retardation caused by ETU was associated with concentration-dependent histological changes in the thyroid gland and increased mRNA expression of TSH-beta in the pituitary ${ }^{33}$. Degitz et al. exposed pre- and pro-metamorphic larvae to methimazole, PTU and T434 and induced changes in a concentration-dependent manner. Methimazole and PTU caused a delay in larval development and morphological changes in the thyroid gland, which were characterized as reduced colloid, glandular hypertrophy and cellular hyperplasia and hypertrophy. On the other hand, T4 treatment resulted in a concentration-dependent increase in 
the developmental rate ${ }^{34}$.

One other potent inhibitor of T4 synthesis, perchlorate, disturbs iodide uptake by the follicular cells of the thyroid gland. Ammonium perchlorate was found to inhibit forelimb emergence, hindlimb development and tail resorption, linked to significant hypertrophy of the thyroid follicular epithelium at concentrations below those reported in contaminated surface waters ${ }^{35,36}$. Tietge et al. showed that sodium perchlorate inhibits TH synthesis via effects on the sodium-iodide symporter, resulting in retarded metamorphosis and histological effects on thyroid as the most sensitive endpoint ${ }^{37}$. Hu et al. reported the results of thyroid immunohistochemistry for T4 in X. laevis exposed to perchlorate ${ }^{38}$; T4 immunoreactivity was concentrated in a ring of colloid adjacent to follicle cells, independent of the developmental stage. Theirs is the only report regarding this point of view, but they suggested the utility of this immunohistochemical biomarker, because the intensity of the colloidal T4 ring is more sensitive than any other morphological changes (such as hind limb length, forelimb emergence, tail resorption, thyrocyte hypertrophy or colloid depletion).

There are limited reports concerning environmental contaminant chemicals. Gutleb et al. found that time until metamorphic transformation was prolonged, the body weights of froglets were increased after exposure to polychlorinated biphenyls (PCB) and T4 levels were lowered, although not significantly ${ }^{39}$. Iwamuro et al. established that bisphenol A (BPA) induced deceleration of both spontaneous and T4-induced metamorphic changes, with suppression of thyroid hormone receptor (TR) beta gene expression ${ }^{40}$. Polybrominated diphenyl ether (BDE-47) and a commercial pentabromodiphenyl ether mixture (DE-71) caused delay in tail regression in $X$. laevis ${ }^{41}$. According to Carlsson et al., autoradiograms revealed high concentrations and long-term retention of 2,2',4,4',5-pentabromodiphenyl ether (BDE-99) in adipose tissue and melanin in frogs exposed as both tadpoles and juveniles, with lower developmental stages suggesting possible thyroid hormone disruption ${ }^{42}$. Fort et al. recorded delayed metamorphosis and enlarged thyroid glands with follicular hyperplasia in X. tropicalis and X. Laevis tadpoles exposed to the insecticide methoxychlor ${ }^{43,44}$.

Regarding actual environmental contamination, Sowers et al. reported that municipal wastewater effluent containing measurable amounts of a variety of pharmaceuticals, personal care products, industrial compounds and natural and synthetic hormones could alter the timing of the metamorphic process in frogs ${ }^{45}$. In their latest report of a field study of the native Wood Frog in the Athabasca Oil Sands region of northern Alberta, Canada, metamorphosis was delayed or not complete at the end of the 75 day study period ${ }^{46}$.

There is not only evidence of inhibitory effects of compounds. Cheek et al. showed that the herbicide acetochlor accelerated forelimb emergence and the beginning of metamorphic climax, apparently by interacting with T3, but also possibly by weakly opposing the inhibitory actions of corticosterone on development of premetamorphic tadpoles ${ }^{47}$.

The doses used in most of these studies were greater than the levels to which anurans are exposed in the natural environment, so further investigations are required to determine whether exposure to chemicals at environmentally relevant concentrations can affect frog metamorphosis.

In contrast to the data showing a clear effect on metamorphosis of chemical compounds, some negative data have been reported. UV filters such as 4-methylbenzylidene camphor (4-MBC) and 3-benzylidene camphor (3-BC) have been found to not affect the thyroid system and the rate of metamorphosis at environmental concentrations, and thus, they seem not to exhibit thyroid-mimicking or antithyroid activity ${ }^{48}$. Carr et al. reported exposure to one herbicide, atrazine, did not exert any effects on metamorphosis 49 .

There are several reports concerning effects on amphibian larvae of triclosan, which is a bacteriocide used in personal care and consumer products such as shampoo, soaps, deodorants, toothpaste and plastic ware, and so on. The release of triclosan into the environment is of particular concern as it is structurally similar to $\mathrm{TH}$. Veldhoen et al. reported that triclosan was found to affect hind limb development in amphibians ${ }^{50}$. And then Fort et al. conducted a GLP study in compliance with the guidelines mentioned below, and indicated that environmentally relevant concentrations do not alter the normal course of thyroid-mediated metamorphosis in this standard anuran model ${ }^{51}$. The effect of triclosan has been controversial ${ }^{52-56}$.

\section{Guideline Establishment}

The amphibian hypothalamic-pituitary-thyroid (HPT) axis controls TH levels in the same way as it does in mammals, although $\mathrm{CRH}$ also plays a role. Therefore, the amphibian metamorphosis assay (AMA) represents a generalized vertebrate model to the extent that it is based on the functions of the HPT axis.

On September 7, 2009, the Organization for Economic Co-operation and Development (OECD) adopted the AMA using $X$. laevis as a guideline for testing of chemicals ${ }^{1}$. The US Environmental Protection Agency (EPA) Office of Prevention, Pesticides, and Toxic Substances (OPPTS) also includes the AMA for detection of thyroid-active chemicals in Tier 1 testing of their endocrine screening program. The EPA developed the OECD test guidelines through a process of harmonization in October 20092. Previously, in 1998, the OECD initiated a high-priority activity to revise existing guidelines and develop new guidelines for the screening and testing of potential endocrine disrupters. One element was a test guideline for the screening of substances active on the thyroid system of vertebrate species. The 1st OECT Expert Consultation on Endocrine Disrupter Testing in Amphibians was held in 2001. Subsequently, the AMA underwent extensive validation programs consisting of 3 phases, which included intra- and interlaboratory studies demonstrating the relevance and reliability of the assay. Mainly the U.S., Germany and Japan took part in these trials.

For validation phase 1, T4 and PTU were chosen as test chemicals ${ }^{57}$. The primary objective was a comparative 
Table 1. Protocol of the AMA

\begin{tabular}{ll}
\hline Test animal & Xenopus laevis larvae \\
Initial larval stage & Nieuwkoop and Faber stage 51 \\
Exposure period & 21 days \\
Larvae selection criteria & Developmental stage and total length (optional) \\
Test concentrations & Minimum of 3 concentrations spanning approximately one order of magnitude \\
Exposure regime & Flow-through (preferred) and/or static-renewal \\
Test system flow rate & $25 \mathrm{~mL} / \mathrm{min}$ \\
Larval density & 20 larvae/test vessel $(5$ larvae $/ \mathrm{L})$ \\
Test solution/test vessel & $4-10 \mathrm{~L}(10-15 \mathrm{~cm}$ minimum water) $/$ glass or stainless steel test vessel \\
& $(\mathrm{e} . \mathrm{g} ., 22.5 \mathrm{~cm} \times 14 \mathrm{~cm} \times 16.5 \mathrm{~cm})$ \\
Replication & 4 replicate test vessels $/$ test concentration and control \\
Acceptable mortality rate in controls & $\leq 10 \%$ per replicate test vessel \\
Water temperature & $22 \pm 1^{\circ} \mathrm{C}$ \\
Lighting & $12 \mathrm{~h} \mathrm{Light:} 12 \mathrm{~h}$ dark, 600 to 2000 lux \\
Thyroid fixation & Davidson's fixative \\
pH & $6.5-8.5$ \\
Dissolved oxygen concentration & $>3.5 \mathrm{mg} / \mathrm{L}(>40 \%$ air saturation) \\
\hline
\end{tabular}

Table 2. Observation Time Points for Primary Endpoints in the AMA

\begin{tabular}{ll}
\hline \multicolumn{1}{c}{ Apical endpoints } & \multicolumn{1}{c}{ Observation time points } \\
\hline Mortality & Daily \\
Developmental stage & Day 7 and 21, comply with N\&F Stage \\
Hind limb length & Day 7 and 21 \\
Snout-vent length & Day 7 and 21 \\
Wet body weight & Day 7 and 21 \\
Thyroid gland histology & Day 21, comply with guidance for histopathology \\
\hline
\end{tabular}

evaluation of the utility and sensitivity of two proposed exposure scenarios for detection of stimulating and inhibiting effects of thyroid system-disrupting substances.

Phase 2 was interlaboratory multichemical testing with a harmonized protocol ${ }^{58}$. The United Kingdom and Switzerland also participated in this phase in addition to Germany, Japan and the United States. Three model substances representing different modes of action on the thyroid system were used: sodium perchlorate, T4 and iopanoic acid (IOP). IOP is an inhibitor of iodothyronine deiodinases.

Phase 3 studies were conducted to assess the utility of the AMA protocol to detect weakly active thyroid systemdisrupting substances and to distinguish thyroid systemrelated changes from activity resulting from mechanisms not directly related to thyroid system function ${ }^{59}$. Benzophenone-2 (BP-2) and E2 were selected as weakly active and non- or indirectly related substances. As a result, the effect of a weakly antithyroid substance, BP-2, was detected, while the endpoints with exposure to E2 did not indicate any effect on the thyroid system. Subsequently, validation of the assay was subjected to peer review by a panel of independent experts.

The procedure in the guidelines is shown simply in Table 1 and Table 2. Exposure should be initiated at developmental stage 51, according to Nieuwkoop and Faber60. Hind limb development is used qualitatively for determination of the developmental stage. The exposure duration is 21 days. The primary endpoints and observation time points are mortality daily, developmental stage, hind limb length,
Table 3. Diagnostic Criteria, Severity and Grading for Histopathology in AMA

Core criteria (severity graded)

- Thyroid gland hypertrophy/atrophy

- Follicular cell hypertrophy

- Follicular cell hyperplasia

Additional criteria (severity graded and/or qualitatively described)

- Follicular lumen area: reduced or increased

- Colloid quality: homogeneous, heterogeneous, lacy or granular

- Follicular cell height/shape: squamous, cuboidal, low/high columnar

Grading (For multifocal or diffusely-distributed alteration, the percentage of tissue area involved should be considered.)

- Grade 0 (not remarkable to minimal, less than 20\%)

- Grade 1 (mild, 30-50\%)

- Grade 2 (moderate, $60-80 \%$ )

- Grade 3 (severe, over $80 \%$ )

snout-vent length and wet body weight on days 7 and 21 and thyroid gland histology on day 21 . The most prominent morphological staging landmark is hind limb morphology, which is positively associated with agonistic effects ${ }^{57,58}$.

Regarding the histopathology of the thyroid gland, the guidelines mention core criteria and additional qualitative criteria along with grading, as shown in Table 3.

For a more detailed understanding, information is available in "Amphibian Metamorphosis Assay: Part 1 Technical guidance for morphologic sampling and histolog- 

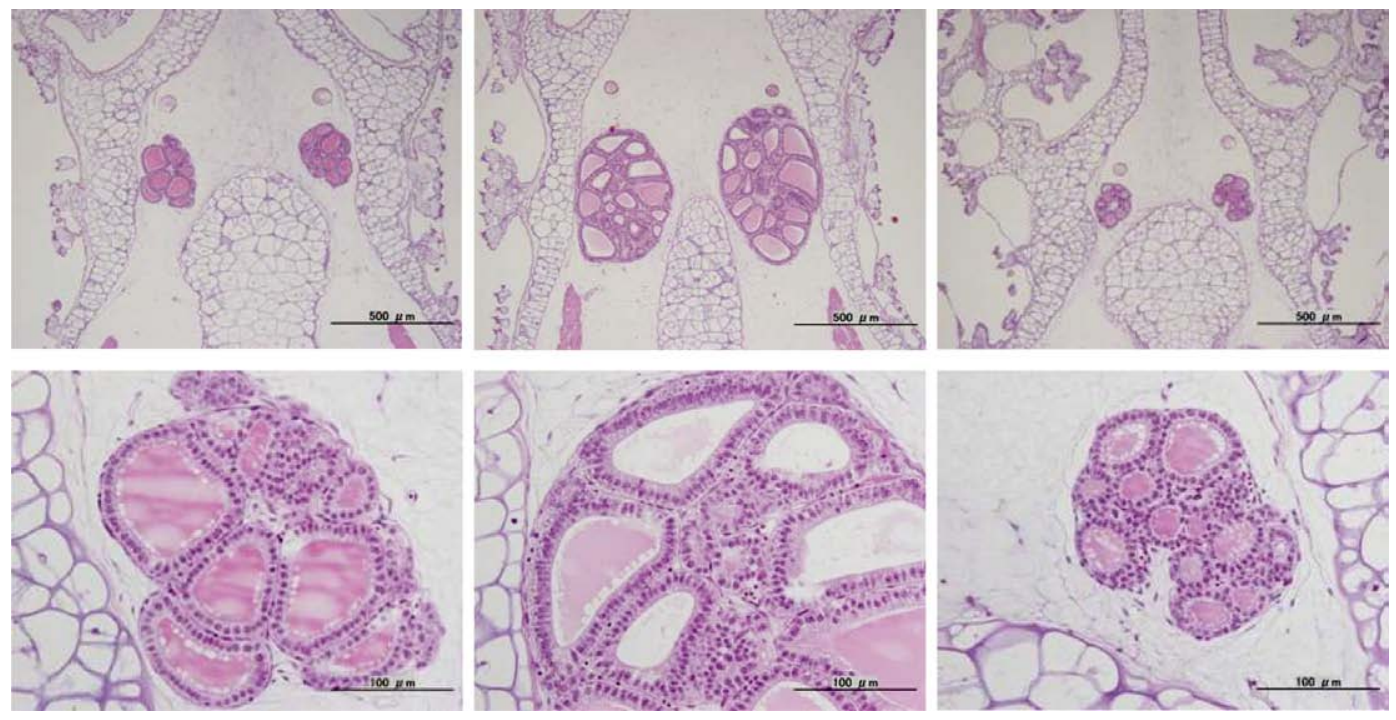

Fig. 4. Thyroid glands after exposure for 21 days beginning at Stage 51. Left: Control. Middle: PTU 25 ppm. Right: T4 $5.0 \mathrm{ppb}$.

ical preparation" and "Amphibian Metamorphosis Assay: Part 2 - Approach to reading studies, diagnostic criteria, severity grading and atlas"61,62. In addition, in support of the OECD AMA test guideline, a document was developed that provides a standardized approach for evaluating the histology/histopathology of thyroid glands ${ }^{63}$, including an atlas of the normal architecture of amphibian thyroid glands over the course of metamorphosis.

One article regarding an examination conducted in compliance with these guidelines supported the use of the AMA as a Tier 1 endocrine screen for detection of potential thyroid pathway activity, but the lack of a true negative response (no effect) during the validation process prevents full evaluation of this assay's specificity at this time ${ }^{64}$.

\section{The Importance and Difficulty of Histopatho- logical Examination}

Each of the mechanisms mentioned above can alter concentrations of circulating THs. Under conditions of TH decrease, a result of feedback of circulating THs on the HPT axis, there is increased secretion of TSH from the pituitary gland. Such excessive stimulation would be expected to result in an increased thyroid gland size, increased degree of follicular cell hyperplasia and/or increased degree of follicular cell hypertrophy, as is well documented for the rodent thyroid gland ${ }^{65}$. O'Connor et al. stated that histopathological change of the thyroid gland is the most valuable information regarding thyroid toxicants ${ }^{66}$, and histological examination of the amphibian thyroid gland has been shown to be a very sensitive approach in several studies. Figure 4 illustrates thyroid glands exposed to T4 or PTU along with controls. Although the developmental stage and hind limb length are important endpoints of antithyroid activity, developmental delay cannot, by itself, be considered a diagnostic indicator of antithyroidal activity. Therefore, conducting histopathological analyses of the thyroid glands is an essential requirement.

A series of validation assays verified that thyroid histopathology is sensitive and reliable for antithyroidal activity resulting from either inhibition of thyroidal iodide uptake or iodide organification. On the other hand, according to the phase 1 validation study, histopathological analyses of thyroid glands of T4-treated tadpoles were less consistent between the laboratories and more difficult to interpret compared with the effects seen in the PTU studies ${ }^{57}$. Furthermore, the phase 2 validation report mentioned that while thyroid histopathology was sensitive for antithyroidal activities, weak agonistic activity could not be reliably detected 58 .

Thyroid histopathology is complex. Depletion of colloid stores and increases in epithelial cell height are known to occur at climax stages during normal development when TSH synthesis and release by the pituitary and T4 synthesis and secretion by the thyroid gland reach maximum levels ${ }^{63}$. Therefore, there may be difficulty in distinguishing whether histological changes occur in response to alterations of the HPT axis or alternatively merely reflect advanced stages in tadpoles. In fact, the guidelines insist that the most appropriate sampling approach for histological analyses is to use stage-matched individuals whenever possible. In order to select stage-matched individuals, all larvae should first be staged prior to selection and subsequent processing for data collection and preservation. This is necessary because normal divergence in development will result in differential stage distributions within each replicate tank.

There is one example showing that amphibian thyroid histopathology is extremely complex ${ }^{53}$, and when misinterpretation occurs, it leads to the opposite conclusion. In a controversial issue regarding the effect of triclosan, Fort 
and Pawlowski reported in regard to the histopathological changes that an increase in the occurrence of minimal thyroid gland hypertrophy was not accompanied by follicular hypertrophy or hyperplasia 54 . The lack of follicular hypertrophy or hyperplasia was suggested to be the result of both the minimal nature of the response and the increased body size of the treated specimens.

\section{Conclusion}

Because disruption of the thyroid axis has been identified as an important consideration for regulation of chemicals, the OECD and EPA have established guidelines that make for use of larval African clawed frogs (X. laevis) and frog metamorphosis for screening and testing of potential endocrine disrupters. In the test guidelines, thyroid gland histology is one of the primary endpoints, along with mortality, developmental stage, hind limb length, snout-vent length and wet body weight. A series of validation studies and many reports have revealed that the histopathology of the thyroid gland is very sensitive and reliable for detection of antithyroidal activity but, on the other hand, is less useful for weak agonistic effects. Since the morphology of the amphibian thyroid gland changes continuously throughout metamorphosis with the fluctuation in TH levels, the guidelines stress the need for well experienced toxicologic pathologists who are familiar with normal $X$. laevis thyroid histology, thyroid gland physiology and general responses of the thyroid gland to agonists or antagonists.

Acknowledgment: The authors would like to thank Dr. Takashi Suzuki for his generous support.

\section{References}

1. OECD Guideline for the Testing of Chemicals: The Amphibian Metamorphosis Assay. OECD231. 2009, from OECD website.

2. Endocrine Disruptor Screening Program Test Guidelines OPPTS 890.1100: Amphibian Metamorphosis (Frog). 2009, from USEP Agency website.

3. Rahman FB, and Yamauchi K. Characterization of iodothyronine sulfotransferase activity in the cytosol of Rana catesbeiana tadpole tissues. Gen Comp Endocrinol. 166: 396-403. 2010. [Medline] [CrossRef]

4. Khan MA, Qadri SY, Tomar S, Fish D, Gururajan L, and Poria MS. Induction of hepatic cytochrome P-450 by phenobarbital in semi-aquatic frog (Rana pipiens). Biochem Biophys Res Commun. 244: 737-744. 1998. [Medline] [CrossRef]

5. Cai L, and Brown DD. Expression of type II iodothyronine deiodinase marks the time that a tissue responds to thyroid hormone-induced metamorphosis in Xenopus laevis. Dev Biol. 266: 87-95. 2004. [Medline] [CrossRef]

6. Huang H, Cai L, Remo BF, and Brown DD. Timing of metamorphosis and the onset of the negative feedback loop between the thyroid gland and the pituitary is controlled by type II iodothyronine deiodinase in Xenopus laevis.
Proc Natl Acad Sci USA. 98: 7348-7353. 2001. [Medline] [CrossRef]

7. Prapunpoj P, Yamauchi K, Nishiyama N, Richardson SJ, and Schreiber G. Evolution of structure, ontogeny of gene expression, and function of Xenopus laevis transthyretin. Am J Physiol Regul Integr Comp Physiol. 279: R2026R2041. 2000. [Medline]

8. Yamauchi K, Prapunpoj P, and Richardson SJ. Effect of diethylstilbestrol on thyroid hormone binding to amphibian transthyretins. Gen Comp Endocrinol. 119: 329-339. 2000. [Medline] [CrossRef]

9. Ishihara A, Sawatsubashi S, and Yamauchi K. Endocrine disrupting chemicals: interference of thyroid hormone binding to transthyretins and to thyroid hormone receptors. Mol Cell Endocrinol. 199: 105-117. 2003. [Medline] [CrossRef]

10. Kudo Y, and Yamauchi K. In vitro and in vivo analysis of the thyroid disrupting activities of phenolic and phenol compounds in Xenopus laevis. Toxicol Sci. 84: 29-37. 2005. [Medline] [CrossRef]

11. Kudo Y, Yamauchi K, Fukazawa H, and Terao Y. In vitro and in vivo analysis of the thyroid system-disrupting activities of brominated phenolic and phenol compounds in Xenopus laevis. Toxicol Sci. 92: 87-95. 2006. [Medline] [CrossRef]

12. Wong J, and Shi YB. Coordinated regulation of and transcriptional activation by Xenopus thyroid hormone and retinoid X receptors. J Biol Chem. 270: 18479-18483. 1995. [Medline] [CrossRef]

13. Kawahara A, Baker BS, and Tata JR. Developmental and regional expression of thyroid hormone receptor genes during Xenopus metamorphosis. Development. 112: 933-943. 1991. [Medline]

14. Brown DD, Wang Z, Furlow JD, Kanamori A, Schwartzman RA, Remo BF, and Pinder A. The thyroid hormoneinduced tail resorption program during Xenopus laevis metamorphosis. Proc Natl Acad Sci USA. 93: 1924-1929. 1996. [Medline] [CrossRef]

15. Tata JR. Amphibian metamorphosis as a model for studying the developmental actions of thyroid hormone. Cell Res. 8: 259-272. 1998. [Medline]

16. Lim W, Nguyen NH, Yang HY, Scanlan TS, and Furlow JD. A thyroid hormone antagonist that inhibits thyroid hormone action in vivo. J Biol Chem. 277: 35664-35670. 2002. [Medline] [CrossRef]

17. Furlow JD, Yang HY, Hsu M, Lim W, Ermio DJ, Chiellini $\mathrm{G}$, and Scanlan TS. Induction of larval tissue resorption in Xenopus laevis tadpoles by the thyroid hormone receptor agonist GC-1. J Biol Chem. 279: 26555-26562. 2004. [Medline] [CrossRef]

18. Kaneko M, Fujisawa H, Okada R, Yamamoto K, Nakamura M, and Kikuyama S. Thyroid hormones inhibit frog corticotropin-releasing factor-induced thyrotropin release from the bullfrog pituitary in vitro. Gen Comp Endocrinol. 144: 122-127. 2005. [Medline] [CrossRef]

19. Suzuki S, and Fujikura K. Circulating thyroglobulin in tadpoles and adult frogs of Rana catesbeiana. Gen Comp Endocrinol. 94: 72-77. 1994. [Medline] [CrossRef]

20. Denver RJ. Several hypothalamic peptides stimulate in vitro thyrotropin secretion by pituitaries of anuran amphibians. Gen Comp Endocrinol. 72: 383-393. 1988. [Medline] [CrossRef] 
21. Jacobs GF, Goyvaerts MP, Vandorpe G, Quaghebeur AM, and Kuhn ER. Luteinizing hormone-releasing hormone as a potent stimulator of the thyroidal axis in ranid frogs. Gen Comp Endocrinol. 70: 274-283. 1988. [Medline] [CrossRef]

22. Jacobs GF, and Kuhn ER. Thyroid hormone feedback regulation of the secretion of bioactive thyrotropin in the frog. Gen Comp Endocrinol. 88: 415-423. 1992. [Medline] [CrossRef]

23. Darras VM, and Kuhn ER. Increased plasma levels of thyroid hormones in a frog Rana ridibunda following intravenous administration of TRH. Gen Comp Endocrinol. 48: 469-475. 1982. [Medline] [CrossRef]

24. Okada R, Yamamoto K, Koda A, Ito Y, Hayashi H, Tanaka S, Hanaoka Y, and Kikuyama S. Development of radioimmunoassay for bullfrog thyroid-stimulating hormone (TSH): effects of hypothalamic releasing hormones on the release of TSH from the pituitary in vitro. Gen Comp Endocrinol. 135: 42-50. 2004. [Medline] [CrossRef]

25. Huang $\mathrm{H}$, and Brown DD. Prolactin is not a juvenile hormone in Xenopus laevis metamorphosis. Proc Natl Acad Sci U S A. 97: 195-199. 2000. [Medline] [CrossRef]

26. Jaffe RC. Plasma concentration of corticosterone during Rana catesbeiana tadpole metamorphosis. Gen Comp Endocrinol. 44: 314-318. 1981. [Medline] [CrossRef]

27. Jolivet Jaudet G, and Leloup Hatey J. Variations in aldosterone and corticosterone plasma levels during metamorphosis in Xenopus laevis tadpoles. Gen Comp Endocrinol. 56: 59-65. 1984. [Medline] [CrossRef]

28. Kikuyama S, Suzuki MR, and Iwamuro S. Elevation of plasma aldosterone levels of tadpoles at metamorphic climax. Gen Comp Endocrinol. 63: 186-190. 1986. [Medline] [CrossRef]

29. Gray KM, and Janssens PA. Gonadal hormones inhibit the induction of metamorphosis by thyroid hormones in Xenopus laevis tadpoles in vivo, but not in vitro. Gen Comp Endocrinol. 77: 202-211. 1990. [Medline] [CrossRef]

30. Hogan NS, Duarte P, Wade MG, Lean DR, and Trudeau VL. Estrogenic exposure affects metamorphosis and alters sex ratios in the northern leopard frog (Rana pipiens): identifying critically vulnerable periods of development. Gen Comp Endocrinol. 156: 515-523. 2008. [Medline] [CrossRef]

31. Carlsson G, and Norrgren L. The impact of the goitrogen 6-propylthiouracil (PTU) on West-African clawed frog (Xenopus tropicalis) exposed during metamorphosis. Aquat Toxicol. 82: 55-62. 2007. [Medline] [CrossRef]

32. Opitz R, Braunbeck T, Bogi C, Pickford DB, Nentwig G, Oehlmann J, Tooi O, Lutz I, and Kloas W. Description and initial evaluation of a Xenopus metamorphosis assay for detection of thyroid system-disrupting activities of environmental compounds. Environ Toxicol Chem. 24: 653-664. 2005. [Medline] [CrossRef]

33. Opitz R, Hartmann S, Blank T, Braunbeck T, Lutz I, and Kloas W. Evaluation of histological and molecular endpoints for enhanced detection of thyroid system disruption in Xenopus laevis tadpoles. Toxicol Sci. 90: 337-348. 2006. [Medline] [CrossRef]

34. Degitz SJ, Holcombe GW, Flynn KM, Kosian PA, Korte JJ, and Tietge JE. Progress towards development of an amphibian-based thyroid screening assay using Xenopus laevis. Organismal and thyroidal responses to the model compounds 6-propylthiouracil, methimazole, and thyroxine. Toxicol Sci. 87: 353-364. 2005. [Medline] [CrossRef]

35. Goleman WL, Carr JA, and Anderson TA. Environmentally relevant concentrations of ammonium perchlorate inhibit thyroid function and alter sex ratios in developing Xenopus laevis. Environ Toxicol Chem. 21: 590-597. 2002. [Medline]

36. Goleman WL, Urquidi LJ, Anderson TA, Smith EE, Kendall RJ, and Carr JA. Environmentally relevant concentrations of ammonium perchlorate inhibit development and metamorphosis in Xenopus laevis. Environ Toxicol Chem. 21: 424-430. 2002. [Medline]

37. Tietge JE, Holcombe GW, Flynn KM, Kosian PA, Korte JJ, Anderson LE, Wolf DC, and Degitz SJ. Metamorphic inhibition of Xenopus laevis by sodium perchlorate: effects on development and thyroid histology. Environ Toxicol Chem. 24: 926-933. 2005. [Medline] [CrossRef]

38. Hu F, Sharma B, Mukhi S, Patino R, and Carr JA. The colloidal thyroxine (T4) ring as a novel biomarker of perchlorate exposure in the African clawed frog Xenopus laevis. Toxicol Sci. 93: 268-277. 2006. [Medline] [CrossRef]

39. Gutleb AC, Appelman J, Bronkhorst M, van den Berg JH, and Murk AJ. Effects of oral exposure to polychlorinated biphenyls (PCBs) on the development and metamorphosis of two amphibian species (Xenopus laevis and Rana temporaria). Sci Total Environ. 262: 147-157. 2000. [Medline] [CrossRef]

40. Iwamuro S, Sakakibara M, Terao M, Ozawa A, Kurobe C, Shigeura T, Kato M, and Kikuyama S. Teratogenic and antimetamorphic effects of bisphenol A on embryonic and larval Xenopus laevis. Gen Comp Endocrinol. 133: 189-198. 2003. [Medline] [CrossRef]

41. Balch GC, Velez-Espino LA, Sweet C, Alaee M, and Metcalfe CD. Inhibition of metamorphosis in tadpoles of Xenopus laevis exposed to polybrominated diphenyl ethers (PBDEs). Chemosphere. 64: 328-338. 2006. [Medline] [CrossRef]

42. Carlsson G, Kulkarni P, Larsson P, and Norrgren L. Distribution of BDE-99 and effects on metamorphosis of BDE-99 and -47 after oral exposure in Xenopus tropicalis. Aquat Toxicol. 84: 71-79. 2007. [Medline] [CrossRef]

43. Fort DJ, Guiney PD, Weeks JA, Thomas JH, Rogers RL, Noll AM, and Spaulding CD. Effect of methoxychlor on various life stages of Xenopus laevis. Toxicol Sci. 81: 454466. 2004. [Medline] [CrossRef]

44. Fort DJ, Thomas JH, Rogers RL, Noll A, Spaulding CD, Guiney PD, and Weeks JA. Evaluation of the developmental and reproductive toxicity of methoxychlor using an anuran (Xenopus tropicalis) chronic exposure model. Toxicol Sci. 81: 443-453. 2004. [Medline] [CrossRef]

45. Sowers AD, Mills MA, and Klaine SJ. The developmental effects of a municipal wastewater effluent on the northern leopard frog, Rana pipiens. Aquat Toxicol. 94: 145-152. 2009. [Medline] [CrossRef]

46. Hersikorn BD, and Smits JE. Compromised metamorphosis and thyroid hormone changes in wood frogs (Lithobates sylvaticus) raised on reclaimed wetlands on the Athabasca oil sands. Environ Pollut. 159: 596-601. 2011. [Medline] [CrossRef]

47. Cheek AO, Ide CF, Bollinger JE, Rider CV, and McLachlan JA. Alteration of leopard frog (Rana pipiens) metamorphosis by the herbicide acetochlor. Arch Environ Contam Toxi- 
col. 37: 70-77. 1999. [Medline] [CrossRef]

48. Kunz PY, Galicia HF, and Fent K. Assessment of hormonal activity of UV filters in tadpoles of frog Xenopus laevis at environmental concentrations. Mar Environ Res. 58: 431435. 2004. [Medline] [CrossRef]

49. Carr JA, Gentles A, Smith EE, Goleman WL, Urquidi LJ, Thuett K, Kendall RJ, Giesy JP, Gross TS, Solomon KR, and Van Der Kraak G. Response of larval Xenopus laevis to atrazine: assessment of growth, metamorphosis, and gonadal and laryngeal morphology. Environ Toxicol Chem. 22: 396-405. 2003. [Medline]

50. Veldhoen N, Skirrow RC, Osachoff H, Wigmore H, Clapson DJ, Gunderson MP, Van Aggelen G, and Helbing CC. The bactericidal agent triclosan modulates thyroid hormoneassociated gene expression and disrupts postembryonic anuran development. Aquat Toxicol. 80: 217-227. 2006. [Medline] [CrossRef]

51. Fort DJ, Rogers RL, Gorsuch JW, Navarro LT, Peter R, and Plautz JR. Triclosan and anuran metamorphosis: no effect on thyroid-mediated metamorphosis in Xenopus laevis. Toxicol Sci. 113: 392-400. 2010. [Medline] [CrossRef]

52. Fort DJ, Mathis M, and Pawlowski S. Triclosan Does Not Affect Thyroid Hormone-Mediated Metamorphosis in Xenopus laevis. Environ Sci Technol. 2011.

53. Fort DJ, Mathis MB, Hanson W, Fort CE, Navarro LT, Peter $\mathrm{R}$, Buche C, Unger S, Pawlowski S, and Plautz JR. Triclosan and thyroid-mediated metamorphosis in anurans: differentiating growth effects from thyroid-driven metamorphosis in Xenopus laevis. Toxicol Sci. 121: 292-302. 2011. [Medline] [CrossRef]

54. Fort DJ, and Pawlowski S. Triclosan enhances larval amphibian growth, but does not alter thyroid-driven metamorphosis in Xenopus laevis. Toxicol Sci. 2011. [Medline] [CrossRef]

55. Helbing C, Wulff J, Bromba CM, Hinther A, and Veldhoen N. Triclosan affects thyroid hormone-mediated metamorphosis in Xenopus laevis. Environ Sci Technol. 2011. [Medline]

56. Helbing CC, van Aggelen G, and Veldhoen N. Triclosan affects thyroid hormone-dependent metamorphosis in anurans. Toxicol Sci. 119: 417-418, author reply 419-422. 2011. [Medline] [CrossRef]

57. Final Report of the Validation of the Amphibian Metamorphosis Assay for the Detection of Thyroid Active Substances: Phase1 - Optimisation of the Test Protocol. 2007, from OECD website.

58. Final Report of the Validation of the Amphibisn Metamorphosis Assay: Phase 2 - Multi-Chemical Interlaboratory Study. 2007, from OECD website.

59. Report of the Validation of the Amphibian Metamorphosis Assay (Phase 3). 2008, from OECD website.

60. Nieuwkoop PD, and Faber J. Normal Table of Xenopus laevis (Daudin). Garland, New York, US. 1994.

61. Guidance Document on Amphibian Thyroid Histology Part 1: Technical guidance for morphologic sampling and histological preparation. 2007, from OECD website.

62. Guidance Document on Amphibian Thyroid Histology Part 2: Approach to reading studies, diagnostic criteria, severity grading, and atlas. 2007, from OECD website.

63. Grim KC, Wolfe M, Braunbeck T, Iguchi T, Ohta Y, Tooi O, Touart L, Wolf DC, and Tietge J. Thyroid histopathology assessments for the amphibian metamorphosis assay to detect thyroid-active substances. Toxicol Pathol. 37: 415-424. 2009. [Medline] [CrossRef]

64. Coady K, Marino T, Thomas J, Currie R, Hancock G, Crofoot J, McNalley L, McFadden L, Geter D, and Klecka G. Evaluation of the amphibian metamorphosis assay: exposure to the goitrogen methimazole and the endogenous thyroid hormone L-thyroxine. Environ Toxicol Chem. 29: 869-880. 2010. [Medline] [CrossRef]

65. Capen CC. Mechanistic data and risk assessment of selected toxic end points of the thyroid gland. Toxicol Pathol. 25: 39-48. 1997. [Medline] [CrossRef]

66. O'Connor JC, Frame SR, Davis LG, and Cook JC. Detection of thyroid toxicants in a tier I screening battery and alterations in thyroid endpoints over 28 days of exposure. Toxicol Sci. 51: 54-70. 1999. [Medline] [CrossRef] 